\title{
Control of the Occlusal Force. Part 4 -Exhibition of Four Cases-
}

\author{
Nobuo Ishihata* ${ }^{*}$, Yoshiaki Nomura *2, Hiroshi Mizutani ${ }^{* 3}$
}

\begin{abstract}
We have been exhibiting the concept of "kamiguse" (the habitual first stroke of mastication), such as definition, background, drawbacks, remedy and so on. And it was cleared that the "kamiguse" (the habitual first stroke of mastication) differs from the first stroke of the habitual mastication. In this article, we present some clinical cases where harmful occlusal forces which seriously influence gnathomatic system were easily controlled by controlling the "kamiguse" (the habitual first stroke of mastication). Also, we discuss and clear the importance of the remedy of the "kamiguse"to control harmful occlusal forces.
\end{abstract}

われわれは，かみ癖の概念についてこれまで披歴してきた。その定義，その生じる理由， その顎口腔系に対する悪影響，その矯正法などについて。そして，われわれのいうかみ癖 とはこれまでいわれている習慣性の咀嚼とは違うということが明らかにされた，本論文で は，顎口腔系に悪影響を与える咬合力が，かみ癖をコントロールすることで簡単にコント ロールできることを明らかにしたいくつかの症例を提示する。また，顎口腔系に害を及ほ す咬合力のコントロールに対し，か及澞の矯正の重要性を論じ明確にする.

Key words : 咬合力 the occlusal force, 習慣性咀嚼 the habitual mastication, 咬合力のコ ントロール control of the occlusal force, かみ癖 kamiguse, the habitual first stroke of mastication, かみ廦の矯正 the remedy of kamiguse 


\section{はじめに}

日常の臨床を行っていくとき，通念，またはそれまでの みずからの経験から積み上げた手法, 考え方では問題が解 決せずに，いつもと違う，何か変だという感じを経験した ことが誰にもいく度かはあるのではなかろうか。そして， それらのうちのほとんどの問題について，何らかの見えな い力が関与しているというところまでは認識できる。が, それが一体いかなる力によるものかについては思いが及ば ないことから，その力への対処のすべがないままに対症療 法を行うといったところが，現状ではなかろうか.

ブラキシズムのような見える力については，患者自身も 認識しやすいため, 対処の方策もあろう。 それに対して, これまで認識されたことのない, 存在するのに見えない力 をどのように捉えるかということについては，顎口腔系に 存在するかみ癖から生じる力について, 顎咬合誌Vol. 24 No. 1 ではその力の捉え方について ${ }^{1}$, 顎咬合誌Vol. 24 No. 2・3ではその力をコントロールするうえでの基本となる 考之方 ${ }^{2)}$, 顎咬合誌 Vol. 25 No. 1. 2 では, かみ癖の矯正 法の基本とその実際について述べてきた ${ }^{3}$.

今回はかみ癖の視点から作ったそれらの理念に基づき, 実際の臨床上で咬合力をコントロールした症例を提示する ことによって, かみ癖から生じる力が顎口腔系に及ぼす影 響を示す。また逆に，かみ癖を矯正することによってその カをコントロールした，つまり咬合力をコントロールした 事実について, 症例を提示しながら詳しく論述する。そし て, コントロールすべき咬合力の対象として, かみ癖に よって生じる力を無視できないこと，また，かみ癖をコン トロールすることが咬合力をコントロールすることに結び つき得ることを明確にする。

\section{症例の提示}

症例については，さまざまな観点から，咬合に関する何 らかの力が問題の発生に関与しているとして間違いがない 明白な症例を取り上げることにした。臼歯部の支持が言失 して下顎前歯部が上顎前歯部を突き上げている，いわゆる 咬合力によって上顎前歯部がフレアーアウトした症例，お よび咬合力により部分床義歯の維持歯が過負荷により重度 の歯周疾患に陷った症例を示古.

\section{1. フレアーアウトの症例}

フレアーアウトの症例を考えるとき，フレアーアウトの 生じる理由として形態的観点からは, 対咬する臼歯部が捛 失したために咬合力を支える支持部が失われ，支持部の䘮
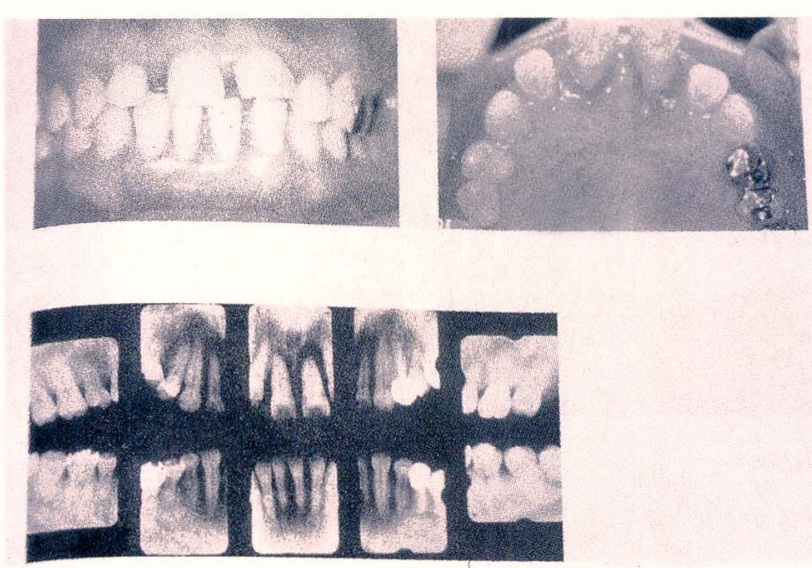

図95 アイヒナーの観点からすれば，臼歯部の支持が 4 カ所に存在 して，上顎前歯部に下顎の突き上げの力など生じるはずがないのに， 上顎前歯部がフレアーアゥトした症例（小林之直, 宮田隆他：歯 周 - 咬合コンプレックス (POC) に関する考察. 日本顎咬合学会誌, 22 : 318-323, 2002 より引用・改変).

失ゆえに下顎の前歯部が上顎の前歯部を突き上げるために 生じるとされる。蝶番運動を基本とする咬合器に装着され た上下の模型について考えれば,まさしくそのようにいえ る. 全㐘列の揃った上下顎石膏模型を咬合器に装着した後, すべての臼歯部を削去し, 力を加えて上下の模型を咬合さ せようとして，石膏模型をカチカチさせてみる。すると， 上下の前歯部のみが接触するようになっているため, 石膏 でできた上顎の前歯部が欠けたり, 下顎の前歯部の切縁が 欠けたりする, つまり, 前歯部に咬合力の負荷が加わるこ とが容易に想像できる。この考え方は歯列の成り立ちとし て, 前歯部の働きはガイド, 臼歯部の働きは顎位の支持と いう考え方に沿っている。 そのような視点を持つと, 久損 㐘の分類でも， 日歯部の支持を重視するアイヒナーの分類 が重視されることになる。

歯列の部分欠損の分類の治療への難易度, またその経過 の良否を分析するために, 近年, 部分床義歯の分野では, アイヒナーの分類を基にした考え方が盛んに唱えられるよ うになっている ${ }^{4)}$. また, 補緅全体としての医療評価のた め, 確固たるエビデンスを得るため, 補経治療に必要な機 能検査の導入を得るための症型分類が，アイヒナーの分類 の考え方を基に作製されつつある ${ }^{5}$. 大雑把に顎口腔系を とらえる方法として, 受け入れやすい方法ともいえる。今 のところでは, 部分床義歯の分野に対しても, 補経全体に 対しても, 試験的に過渡的な状況として, 形態的な面を重 視するこのような方法を採らざるを得ないのではなかろう かと思う。

しかし，われわれは臨床上で図95のような症例に出会 

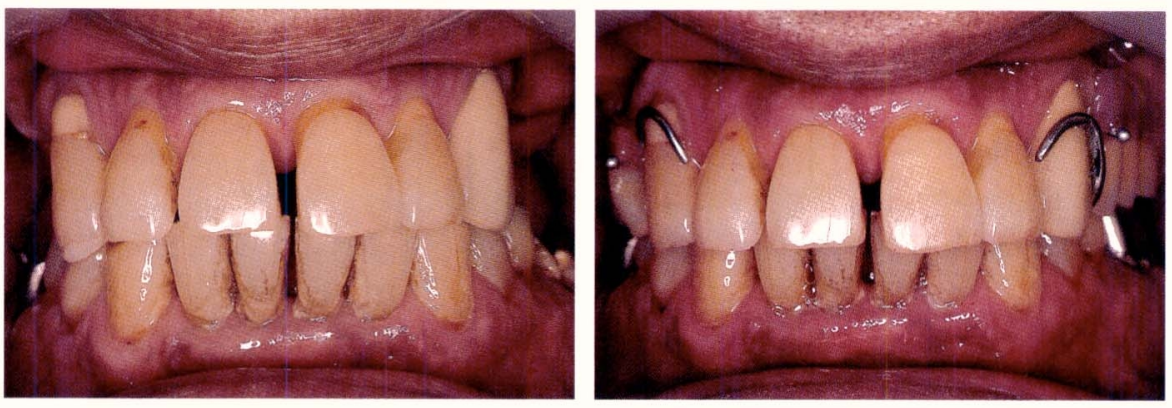

図 96 「最近，上顎の隙間が広がってきた」 と訴える。

図 97 臼歯部の欠損は義歯により補緅されて いた.
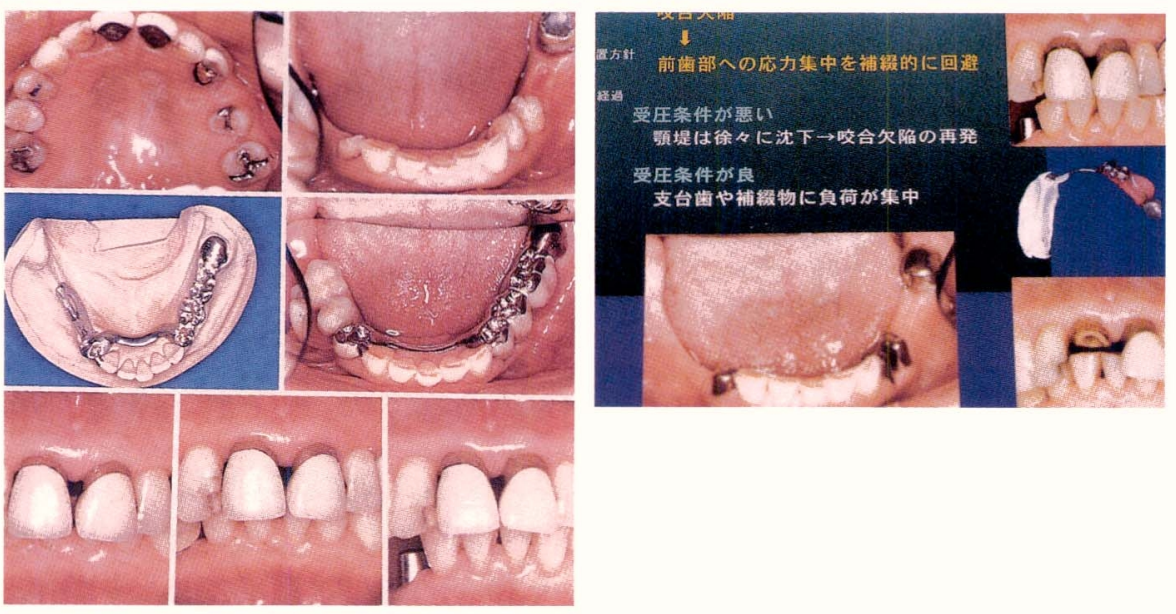

図 98-a 部分床義歯で強固な支持を確立した にもかかわらず, 経時的に再び支持部が崩壊し， 上顎前歯部に異常な負荷が加わつた症例. 兒歯 部による支持の確立で上顎前歯正中の間隙が消 失した。

図 98-b 咬合欠陥が再発したため，11 がコア ごと脱離した。

${ }^{\left.{ }^{6}\right)}$. アイヒナーの分類の考え方では，4つの支持部が あって顎位が確実に保持されているため, 前歯部がフレ アーアウトするはずがないのに，臼歯部が全部そろってい てフレアーアウトしてしまう症例が実在する。また, 現在 世界中で広く使われているケネディーの分類についても， 左右に妇歯部の支持が存在するのに, 左右前歯部のみが欠 損する IV 級というものが存在する。アイヒナーの考え方で は絶対に生じることのない，またその考え方では説明のつ かない欠損形態なのである。且歯部の支持が得られなくな ると, 前歯部に問題が生じるというアイヒナーの考え方は, 形態的な観点からいえばきわめて分かりやすい考え方では ある。しかし，傊様式の捉え方としてそういった問題が あるために，世界中で広く取り入れられなかったと理解す ベきなのではないかと考える。部分床義歯の分類でも, ケ ネディーの分類がメジャーであって，アイヒナーの分類が マイナーでしかない理由が分かる.

かみ癖による下顎の動き方の制限によって，歯列上への 負荷が均等には加わらないとするのがかみ癖の視点であ る.そんな視点から, 前歯部のフレアーアウトした症例に 対して, 咬合力のコントロールを伴う対処の方法を示すこ とにより，そのあたりの問題にも答えが与えられるのでは ないかと考える。

\section{症例 1}

・患者：56 歳男性

・主訴：最近前歯部の正中間隙が広がってきた（図96）. その理由を知りたい

・ 口腔内状況：上顎の臼歯部欠損が義歯により補経されて いた（図 97）。しかし，患者は義歯を普段は外している ことが多く, 食事の時しか使っていない. しかも時々は食 事のときも外す，と言う。

・従来の処置法：上顎臼歯部をなす義歯の咬合高径が, 顎 堤の吸収や臼歯部人工歯の咬耗により低下したために，顎 位の支持が困難となって，下顎前歯による上顎前歯の突き 上げが生じたと考える。そのため，臼歯部のバイトを上げ る方法を採る。しかし，無理に臼茵部のバイトを上げても 経時的に再びバイトが低下して, 上顎前歯部に力の加わる 状況になりかねない（図 98） ${ }^{4)}$. また，義歯の破折，義 歯床下の痛みの発生, 維持歯の動摇ということにもつなが り得る。短期間で悪循環が繰り返される.

しかも，患者は通常は義歯を外している，またときには 食事時にも外すとのことで, 義歯によるバイトの挙上が, 即, 前歯部の突き上げの解除に結びつくとは限らない.

・かみ癖の視点からのアプローチ：かみ癖を調べると, 義 
図99 かみ癖は, 義歯の装着の有無にかかわ 5す左側.
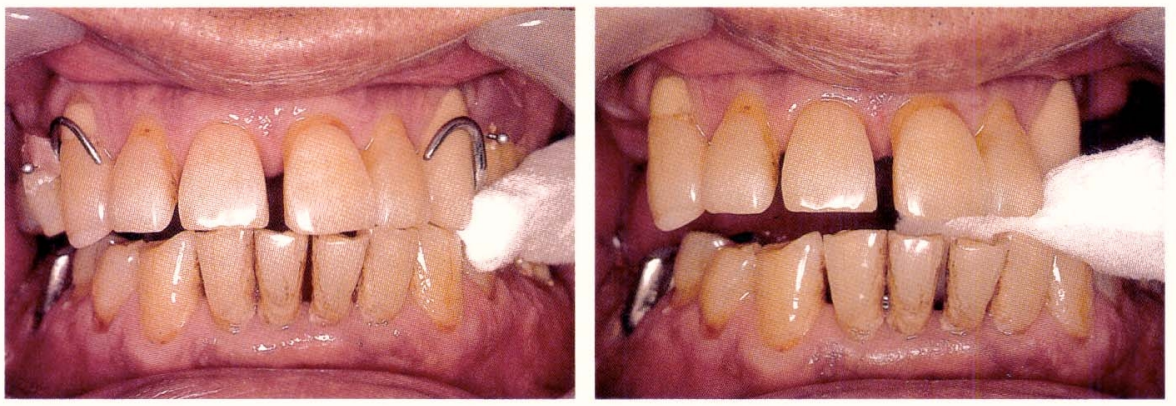

図 100 ロールワッテを左側でかむときには， 下顎を十分左側へずらす。

3|の尖頭には光重合レジンが築盛してある.

図 101 ロールワッテを右側でかむときには， 下顎をほとんど右側へずらさない。
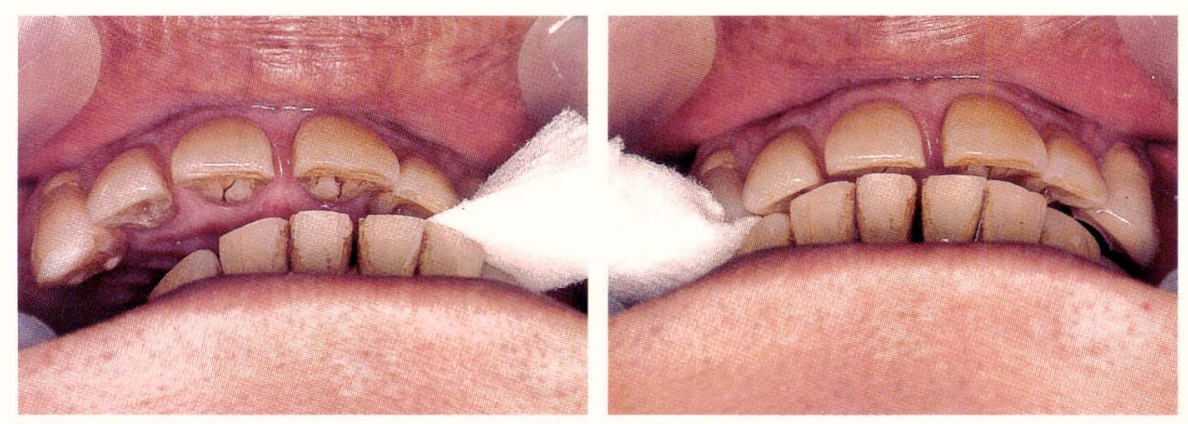

図 102 ロールワッテを前歯でかむときには, 上顎前歯を押し出すようにかむ.
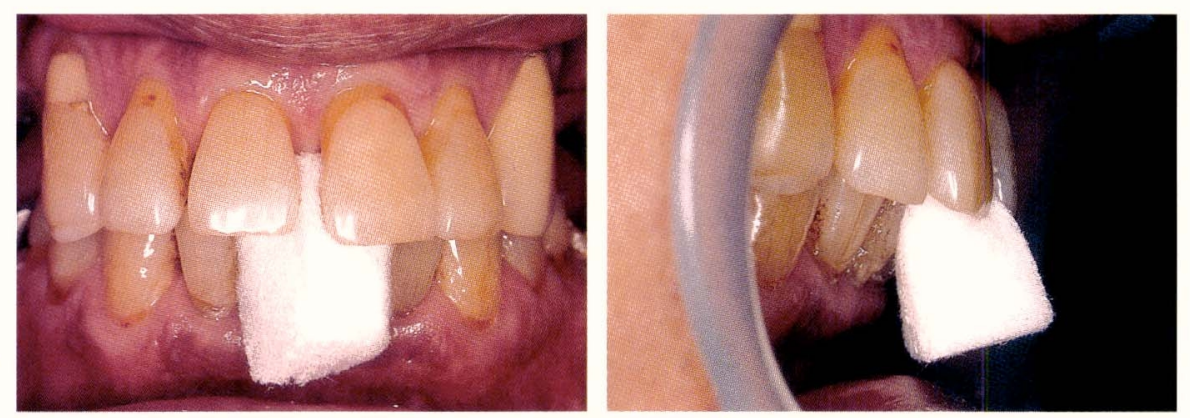

歯の装着時でも，装着していないときでも左側（図 99） である。ここから，左側の下顎頭の動きが悪化しているこ とが分かる。実際に，左右でロールワッテをかませてみる と, 図100のように左側でかむときには, 下顎を十分に 左側へ側方運動させてかむのに対して，右側でかむときに は，図 101 のように下顎を右側へ動かすことなく，ほと んど蝶番運動でかむ。咬合力が左側へ偏位して加わること が分かり，実際によく観察すると，右側前歯より左側前歯 が左に開いている（フレアーアウトしている）のが分かる (図 99)。また前歯でかむように指示すると, 下顎を後退 させたままの状態で, 蝶番運動のみで上顎前歯の口蓋側に ロールワッテを挟んでかもうとする。顎前歯部を前方へ 押し出すばかりである(図 102).

-かみ癖の視点からの処置法：患者に対して，自分の䫣口 腔系の動きを鏡を見せながら認識させる。そして, まず左
側の下顎頭の前下内方の動きをよくするために，3 部でも のをかむように指示した。そして，3部を知覚して，その 部位でものがかみやすくなるように，3 の切縁に光重合レ ジンを盛り足した（図 100）。さらに，前歯でものをかむ ときには，下顎を正確に前下方へ滑走運動させ，上下前歯 の切縁でロールワッテをかむように教示した（図 103）.

・経過観察：数回咬合調整をして 2 週間後に上顎正中の間 隙は狭くなった。患者は, 正中の間隙が広がる理由を知り たかったので，かみ方に注意すれば，広がることがないと いうことで納得した (図 104)。 且歯部に間隙が生じたの で，人工歯の上に即時重合レジンを盛り足し，義歯の高さ を調整した。

その後，6年が経過した電話連絡によれば，教示された ように右でものをかみ, 前歯でかみ切るように注意してい て, 隙間が大きくなるようなことはないということである. 

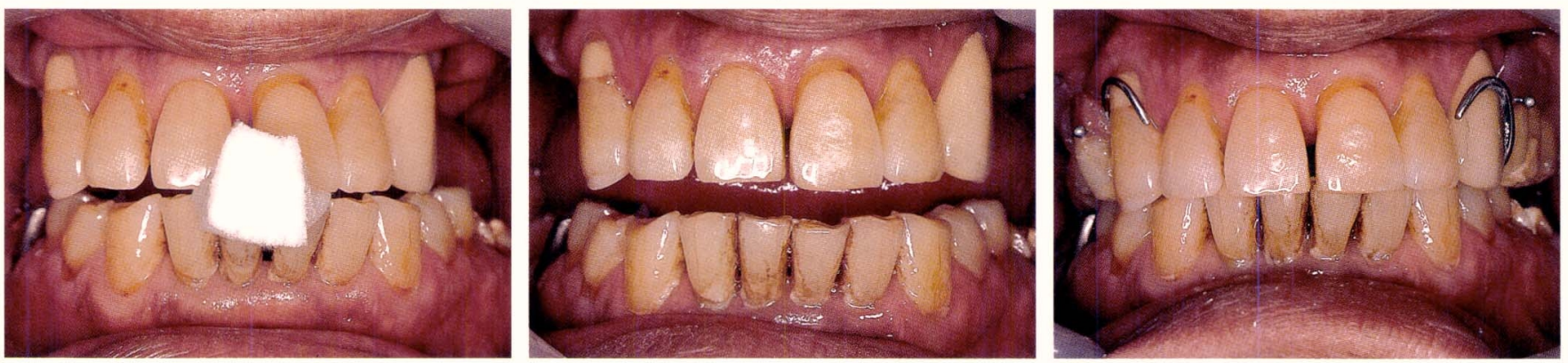

図 103 ロールワッテを下顎を前方へ滑走さ 図 104 間隙が狭まる. 臼歯部の支持がなくてもフレアーアウトは治まる. せた状態でかむように教示した。

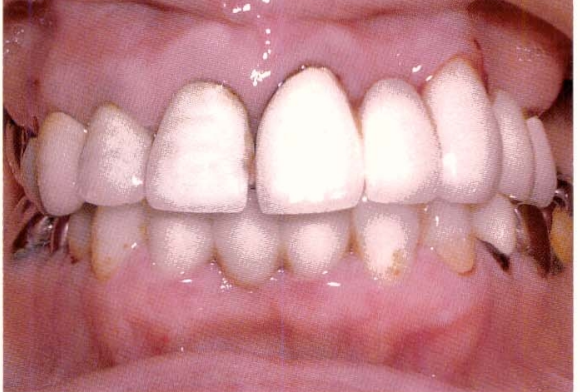

図 105 アイヒナーの観点からすれば，支持 は 3 カ所に存在するのにフレアーアウトして いる

\section{症例 2}

(本症例は，賀来氏の提供によるものである.)

• 患者：64歳女性

・主訴：上顎正中に間隙が生じ，ブリッジが動摇して痛む。

・ 口腔内状況：2467 が欠損していて， (1)〜 (3)〜 (5)のタ ルボンドのブリッジで補綴されていたが，67 は補綴され ていなかった。臼歯部の支持が 3 つ存在しているにもかか わらず，下顎前歯の突き上げにより，正中に間隙が生じて いた（図 105)。【1の遠心口蓋側の歯周ポケットは7ミリ となっていた(図 106).

- 従来の処置法：歯周状態の危うい 1 を抜歯後, (3)(2) (1) 〜3〜 (5)のブリッジを再製し，67に対してはブリッジに 強固に連結をする義歯を制作することにより，臼歯部の支 持を確実にして，下顎前歯部の突き上げる咬合力をコント ロールすることを目指す。

-かみ癖の視点からのアプローチ：かみ癖は左側で, 左側 への側方運動はできるが，右側方運動はまったくできな かった。このことは，歯列が大臼歯部までそろった右側部 へは咬合力による負荷が加わり難く, 症状の生じている左 側部へ負荷が加わりやすくなり，過負荷に陥っているとい う理不尽な状態になっていることを示す。

・かみ癖の視点からの処置法：動きの悪化した左側の下顎
頭に可動性を与えるため，543にスプリントを装着して， 右側の犬歯，第一小妇歯部でものをかむように指示した (図 107). 咬合力で生じる負荷を，かみ癖側を右側にす ることにより，問題のない歯列の揃った右側に分配するこ と劣目指す。

・経過観察：2週間後にフレアーアウトは止まり，【1の遠 心口蓋部に存在した歯周ポケットは驚くべきことに，炎症 がまだ残存しているのに 2 ミリとなた（図108）。

\section{症例 3}

·患者：46歳男性

・主訴：21|1 がぐらついてうまくものがかみ切れない.

・口腔内の状況：かみ合わせが深く，久損は見られない. 大臼歯部が存在するにも関わらず，下顎前歯が上顎前歯を 突き上げる状況になっているために，21|1 部の歯漕骨の 吸收が高度に進行していた。そのために上下前歯部でもの をかもうとするとき，上領前歯部がぐらついてうまくもの がかめない状態であった（図 109）。かみ癖は右側（図 110).

・従来の処置法：通法では $21 \mid 1$ 抜去後, (3)21|1(2)(3)ブ リッジにする。また低バイトに対して，臼歯部の咬合を挙 上する処置を行うことも考えられる。

・かみ癖の視点からのアプローチ：かみ㾕は右側で，右片 

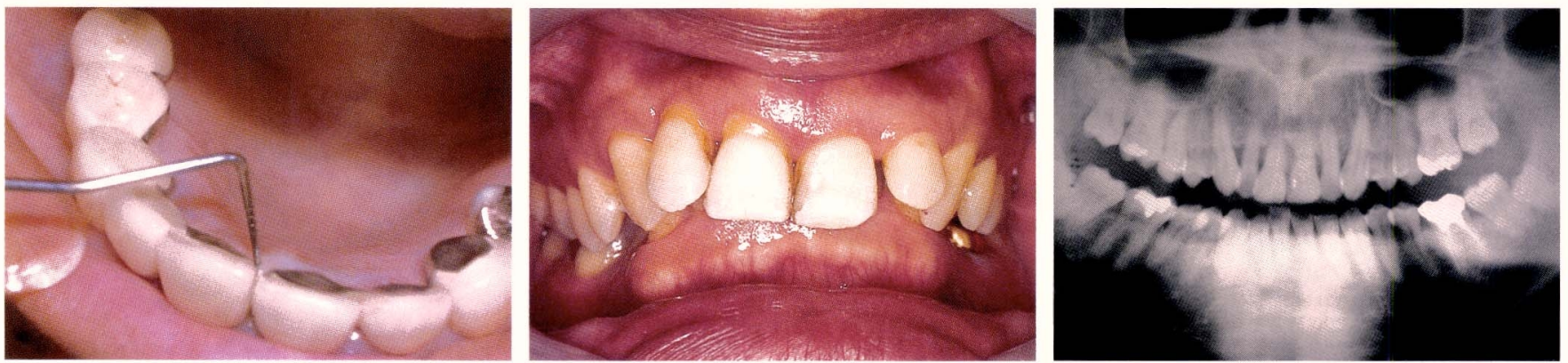

図 108 フレアーアウトも治まり，歯周ポ 図109 バイトが非常に深く，右側前歯部の骨吸収の方が左側より重度である ケットは $2 \mathrm{~mm}$ となる

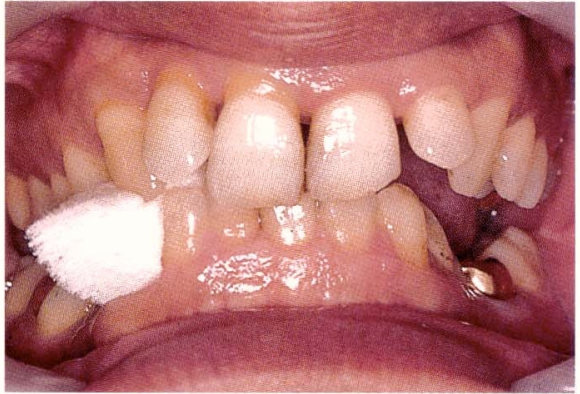

図 110 かみ癖は右側である。

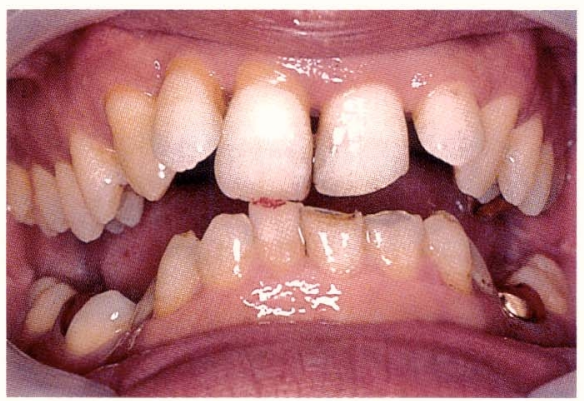

図 113 正確な前方滑走運動を行うと，左右 上下臼歯部の間隙は等しくなる。

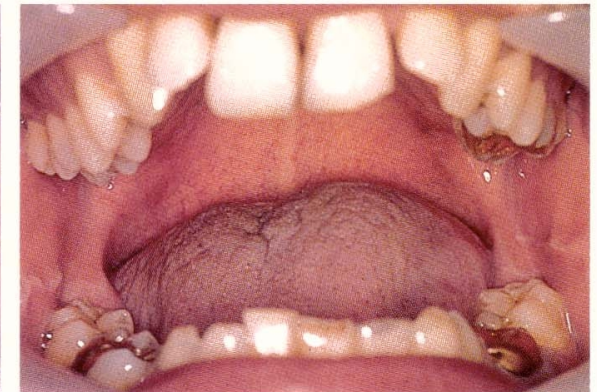

図 111 右へ傾斜する舌は右がみを示し，右 片側がみの悪影響といえる

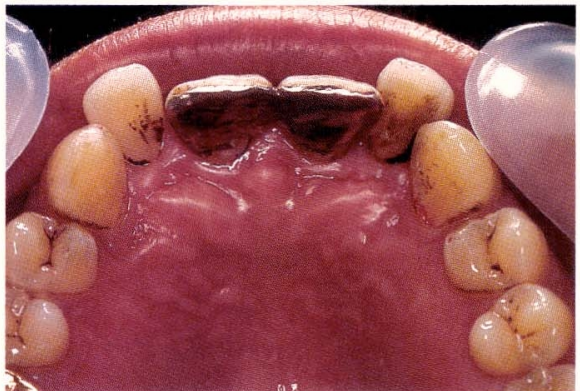

図 114 前がみさせるため, 動摇する 1 を連結した

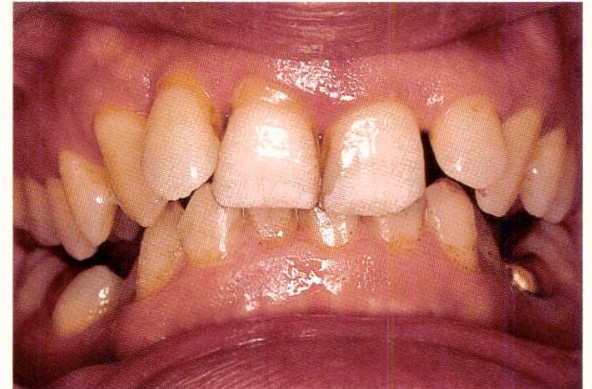

図 112 前方滑走運動時に, 左右の上下臼歯 部の間隙が等しくなく, 左側の方が広い

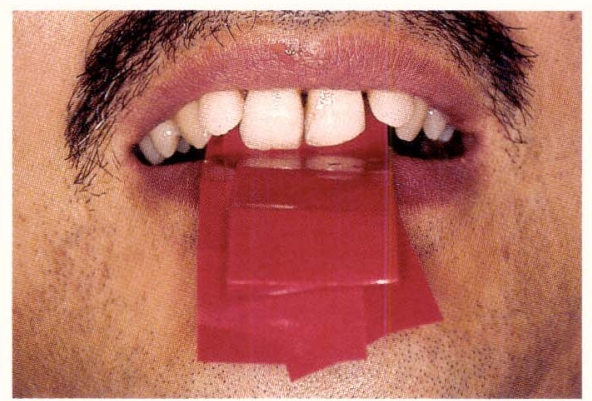

図 115 前がみをさせるために，切縁同士で かめるように咬合調整した
側がみの悪影響を受けて舌も極端に右下がりである（図 111 ). 右側へは側万運動ができるが, 左側へはまったく 側方運動ができなかった。

- かみ癖の視点からの処置法：前方運動時の状況を図 112 に示すが, 明らかに, 右側臼歯部の間隙が左側より 狭いのがわかる。これは, 前方運動時に右側の下顎頭が前 下方へ十分な滑走運動をしていないことを示す. 前方運動 時に左右の下顎頭が十分な滑走運動を行っていれば, 図 113 のうに左右臼㐘部にほぼ均等な間隙が空くはずで ある. 左側の下顎頭は前下方へ滑走運動しているにもかか わらず，そのとき右側の下顎頭は蝶番運動を行う後退位に あるとみられる。
- かみ癖の視点からの処置法 : 前方運動時, 右側の下顎頭 も前下方へ滑走運動を行えるように，前がみをさせるため に1|1にピンレッジを制作した（図１14）。連結して動摇 を抑え，前がみをさせるために前歯切端位を教示し，もの をかむときにその顗位でかみ切るように指示した。また， 肉や野菜など前歯でかみ切りにくいものをかむときには， 左側の犬歯部を使うように指示した。前がみにより前歯切 端位の使い方が上手になるに伴い, 上下前歯の削合をおこ なった (図 115)。そその結果, 前がみができるようになっ て前柬部の動摇はコントロールされ, 舌の極端な右下がり も改善された（図 116).

・経過観察：処置後 9 年経過しているが, 前歯部の歯周の 


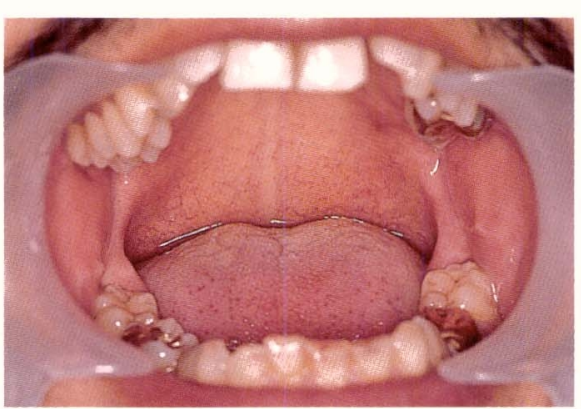

図 116 右片側がみによる舌の右下がりは, 改善された。

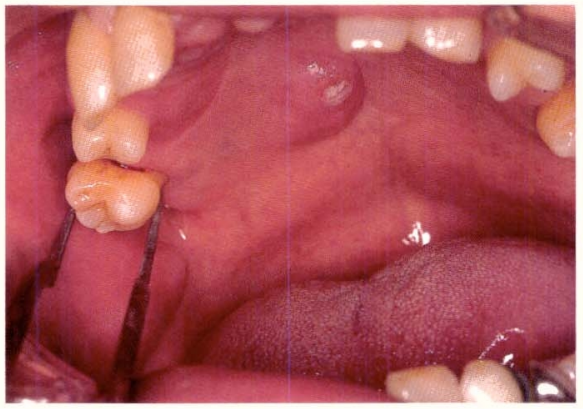

図119 7 の動摇が大きく, 近心部から排膿 図 120 舌の右傾斜が認められた. も認められる。 ていた.

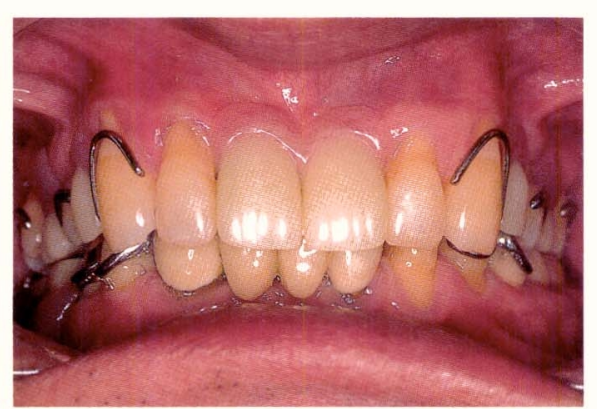

図 117 欠損部は部分床義歯により補綴され

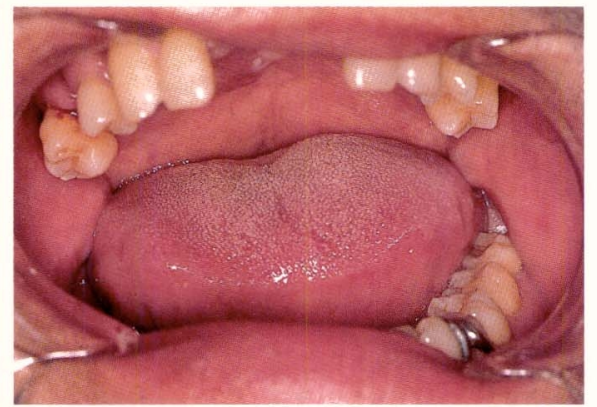

\section{.}

状態が恵化することはなく, 前歯部でものがかみ切れてい るとのことである.

\section{2. 維持歯が歯周疾患に陥つた症例}

歯周疾患に陥った歯をブリッジで連結することにより 救ったという症例報告は多々ある。しかし, 部分床義歯の 維持歯として使用しながら重度の歯周疾患に陥った歯を， その部分床義歯にリライニングなどほとんど手を加えるこ となく, 部分床義歯として機能させたままで歯周の状態を 改善するということは, これまで試みられなかったことが ないのは，ご承知の通りである。

\section{症例 4}

・患者：59歳男性

・主訴：維持歯75 の動摇と7 の疼痛

・ 口腔内状況: $\frac{6411146}{76}$ が久損して, 欠損部は部分床義歯に よって補経されていた（図１１7）。7は３３に近い状態， 5」はM2，32|7はM1の動摇だが，235 はM0であった。 また義歯の床縁の圧痕が右側で梁く，一部では口蓋粘膜に エロージョンが認められるほどであった（図118）７〕の 近心歯肉縁からは排膿も見られた（図１19）。舌の右傾斜 わざわざ問題の生じている7でかむ.

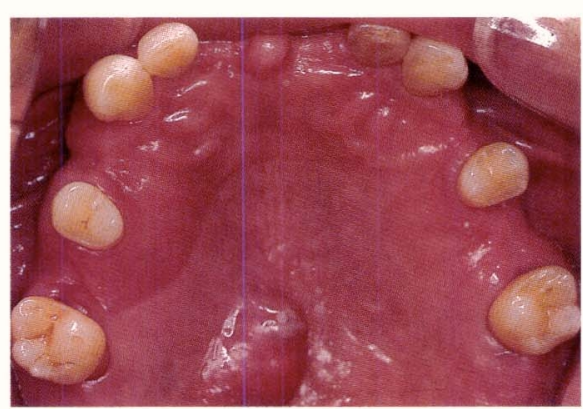

図 118 右側の残存歯の動摇が大きい，床緑 の圧痕は, 右側では深くてエロージョンも認め られるが, 前歯部, 左側ではほとんど認められ ない.

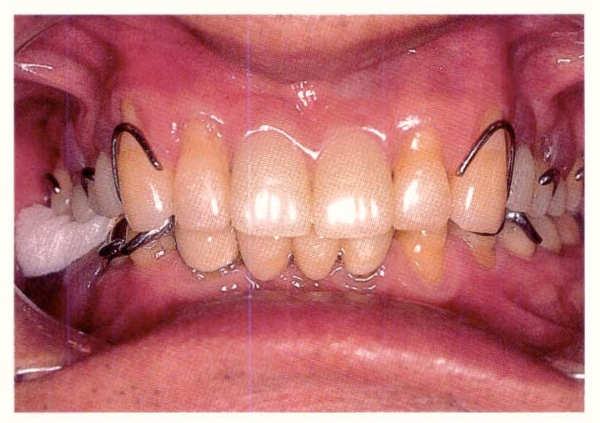

121 かみ癖を調べると、、ールワッテを

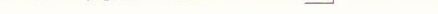

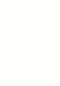

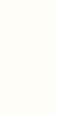



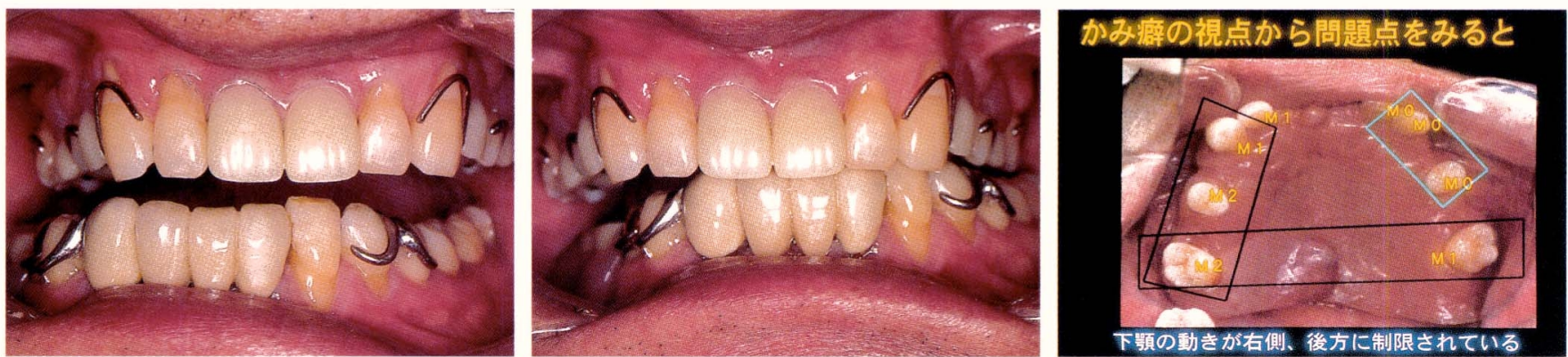

図 122 ：下顎犬歯が，右側へは上顎犬歯を超えて十分な側方運動ができるが，左側へは上顎犬 歯を超えることができない. ると，奥がみと右片側がみになっている様子が 分かる.
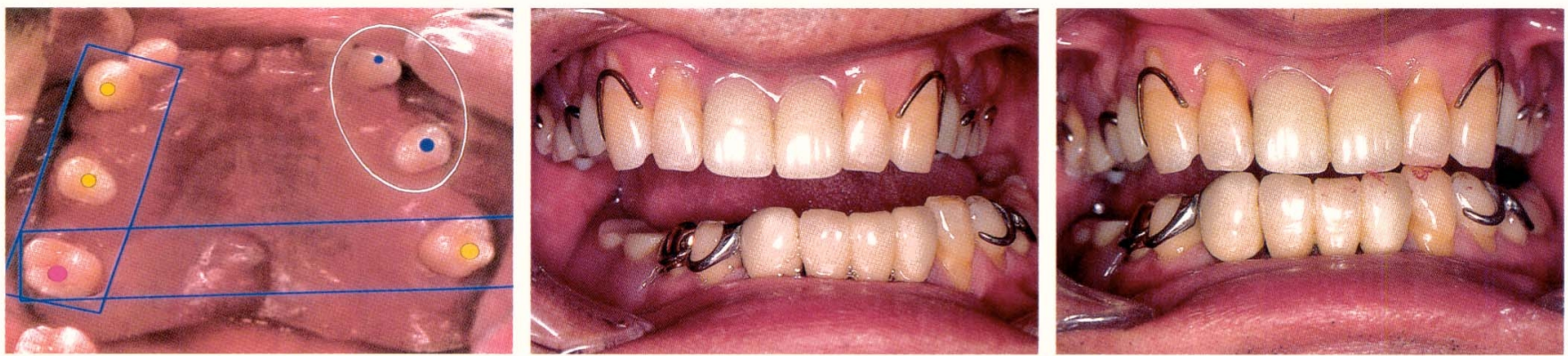

図 124 左側側方運動のやり方を教えて，問 図 125 初診時にはできなかった左側への側 題の生じていない左側の犬歯，第一小臼歯部で 方運動が簡単にできるようになる ものをかむことを教示した。 で枵位が保持できやすくなるように咬合調整を 行った.
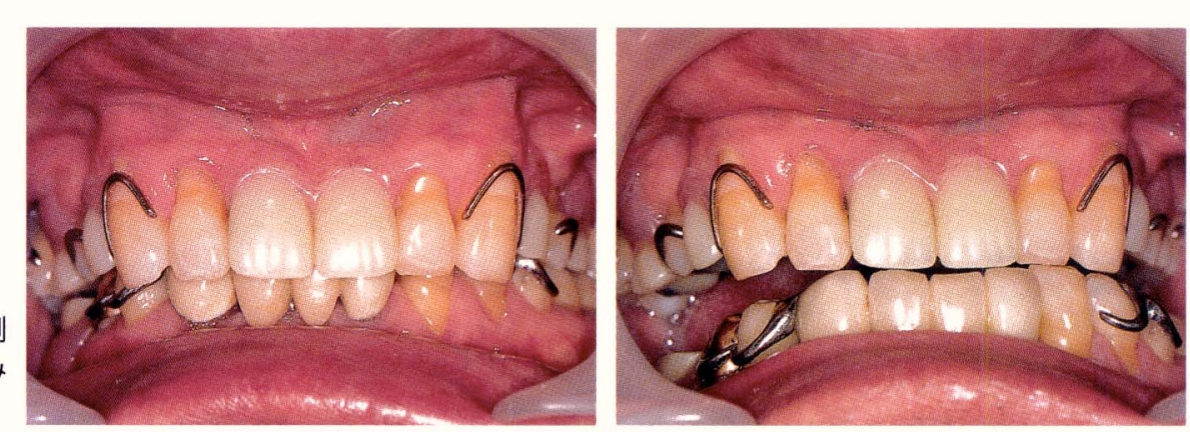

図 1278 年後の状態

図 128 かんでくださいの指示に，やや左側 ではあったが前方位で下顎を支持した，前がみ になっている.

かむことができなくなっている，【にに過負荷の加わる状況 である、

まず，患者に維持歯へのブラッシングとともに，左側側 方運動のやり方を教えた後, 問題の生じていない左側の犬 歯, 第一小臼歯部でものをかむことを教示した (図 124). その結果, 左側への滑走運動もスムーズに行えるように なった（図 125). 左側でかむようになったためか，M0 であった 5 が，M2の動摇を示したので咬合調整を行った。 これまでの解釈からすると， 5 に早期接触があったため に，下顎の左側側方運動が障害され，右側歯列しか使えな かった。となるのであるが，かみ癖の視点からすると，ど うして必ず早期に接触する早期接触部が咬耗しないで残っ
ているのか, ということになるのである. が, 紙面の関係 で詳しい説明は別の機会に譲る。

かみ癖の矯正を行ってから 2 週間後, 7 の動摇度はM1 に，5」はＭ０にと良好な状態に回復した。床縁の圧痕は まだ右が深い.その後, 側方だけでなく, 顎口腔系に害を 与えないとされる前がみをさせるために, 前歯切端位で咬 合調整を行った（図 126）.

4 年半経過時に患者さんが退職されて以来, メインテナ ンスはまったく行っていなかったが, 初診から8 年経過後, 経過観察のために来院していただいた（図 127）。診察時 に, 顎口腔系にもっとも悪影響の少ないとされる前方位で, やや左側ではあったが，下顎を支持した（図 128）。また， 


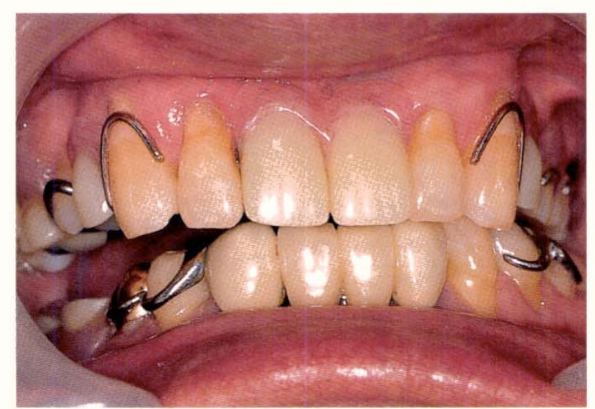

図 129 左右側へほぼ均等に側方運動ができる.

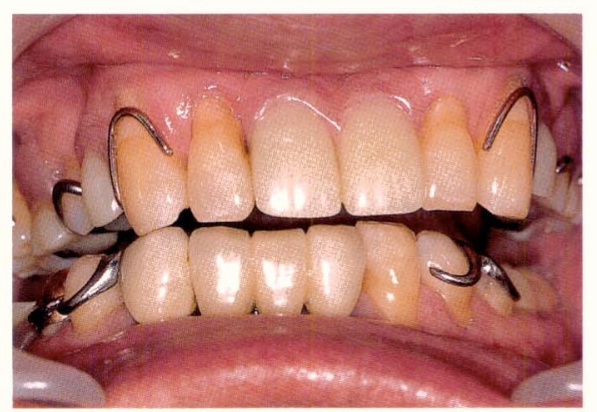

図 130 床縁の圧痕が，左右と前歯部も均等 になっているのが見て取れる. 圧痕の深さは初 診時よりも全体的に深いことが分かる.

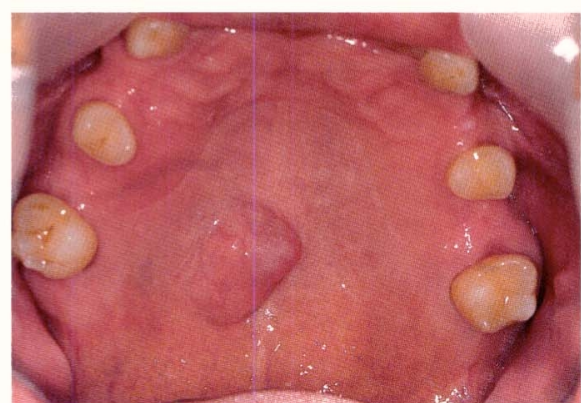

左右側方運動はほほ均等に行うことができた（図 129）. 問題の維持歯は驚くべきことに M0 となり，他の維持歯の 動摇度も M0 となっていた。床縁の圧痕も, 前歯部も含め て左右均等になっていて，下顎の動きに制限のない前がみ となり歯列のすべてを均等に使っている状況を示した（図 130).

\section{3. 前がみと奥がみ，片側がみについて}

これまで，かみ癖の視点から顎口腔系の健康の保持に大 きな影響を与える，もののかみ方について論述してきたが， ここでおさらいしておく、顎口腔系には，顎位不定になら ない上うに，その神経系統にものをかむうえでのループ化 を作る必要がある. 左右側の下顎頭の動きに差が存在して, かみ癖を作ることによりループ化を形作るようになってい ることについては前に詳述した（Vol. 25 No. 1・2の図 59 参照).

左右側一方の下顎頭の動きの悪い側が, かみ癖側となる. 左側と比較して右側の下顎頭の動きが悪い場合には，右側 が作業側となって右がみとなる．右側と比較して左側の下 顎頭の動きが悪い場合には，左がみとなる。このときの㴿 口腔系をみると，かみ癖側では下顎頭に加わる力が前下方 への力より後上方への力が勝っている。一般的な健常な䫟 口腔系でも，ものをかむのにかみ癖側の下顎頭が後上方へ 引っ張られて,かみ癖側の臼菌部が使いやすくなっている. この後上方への力が強まることによって，かみ癖が固定化 しやすい状況になる，かみ癖側での後上方への力が強まっ て，かみ癖側の下顎頭の動きがさらに悪化すると，右ある いは左片側がみとなり，そのサイドの臼歯歯列しか使えな くなる。また，反対側の下顎頭の動きまで悪化すると，左 右の大印歯部しか使えない奥がみとなる。片側がみや奥が みでは，咬合力によって生じる負荷を，全歯列のうち一部 の歯列部位にしか加えられない状況になる（Vol. 25 No. 1, 2 の図61参照)。その負荷が累積して大きな力となって過 .

負荷になり，歯列に害を及ばすり。

しかし，中には，かみ癖側でも後上方への力をうまく制 御できて, 前下方への力が後上方への力より勝る状沉にあ るために，かみ癖側の下顎頭も前下方への動きが良好な場 合がある．左右両側の下顎頭の前下方への動きが良いため に，かみ癖が固定化しにくい状況になっている．また，下 顎が前方向へ動きやすくなっている。これが ‘前がみ’の 状態である。前がみについては，顎咬合誌Vol. 25 No. 1 ・ 2 , 咬合力のコントロールその 3 , かみ癖の矯正“前がみ の重要性”に詳述してある。顎口腔系にまったくといって いいほど害を与えないとされるかみ方，下顎の使い方，動 かし方である。前がみができるということは, 咬合力に よって生じる負荷を, 健全な歯列各部位に適切に配分する ことが可能である，片側がみや奥がみのように，咬合力に よって生じる負荷が歯列の一部に累積するということが防 げる。これまで考慮されることのなかった, 負荷の累積に よる害を防止できる。咬合力による負荷の累積による害を 防止するためには，この前がみというもののかみ方を有効 に利用するのである22.

これまでの認識からすると, ‘前がみ’とは前歯部のみ が接触する咬合状態をいう。インプラントの分野を例にあ げると，上顎が全部床義歯で下顎にインプラントを入れた 場合, 最初に適切な咬合状態を与えても, 時間の経過とと もに前歯部のみが接触するようになる。顎前歯部が下顎 前歯部により突き上げられ，上顎前歯部の顎堤がフラビー ガムになっていく。このような状況を指して，すなわち臼 歯部のバイトが低下したために上下前㐘部が衝突するよう になる状況を前がみと称する場合が一般的ではあるが，か み癖の視点でいう前がみとは，まったくこれとは異なる。 再度強調するが, かみ癖の視点での前がみの要件としては, 簡単に述べると, 両側の下顎頭が同時に前下方に滑走運動 した状態で，上下前菌部が接触してものをかむ状況になる ことをいう。言い換えると, 滑走運動した状態で䫈位が定 
まる，すなわち，両側の下顎頭を滑走運動した位置で，そ の二点を回転軸とする蝶番運動によって閉口し，上下前歯 を接触させる，接触させた上下顎前歯を一点と，両側の下 顎頭の二点，都合三点で顎位を保持する。このような状況 で，等尺性収縮によってものをかみ，その位置から両側の 下顎頭の後方への滑走運動により下顎を後退させ，咬頭嵌 合位に下顎を戻せる状態にある。そのような経路を経ても のをかむときのやり方を，かみ癖の視点における前がみと 呼ぶのである．前者とどこが違うのかというと，上下前歯 を接触させるときに滑走運動を行った状態にあるかないか ということ，顎位を前歯の接触点と下顎頭の三点で定める ことができるかできないかということにある。また，顎位 の保持に自歯部の咬合が必要か否かということにある。例 に出したインプラントの場合では，開口から閉口するとき に蝶番運動で下顎を閉じて，上下前歯が接触してもその位 置で顎位を保持することができずに閉口という行為が継 続，上下の且歯部が接触して初めて顎位が保持できるよう になる。また，その間，下顎前歯は上顎前歯を突き上げる という状況になり，前でかんでいるようには見えるが，一 切滑走運動が含まれずに蝶番運動でのみ下顎が動くという 状態になっている。このような状態のとき，ものをかむ場 合にいくら前歯部を使っているように見えても，かみ癖の 視点からは前がみとは言わない，かみ癖の視点からは，蝶 番運動のみを使って下顎の運動を行うように見えるのであ るから，あえて言えば，顎口腔系に悪影響を与えるとされ る ‘奥がみ’と同じ状況になっているのである.

\section{4. 症例に当てはめてみると}

かみ癖の視点での前がみは，症例 $1 ， 2$ に如実に示され ている．前下方へ滑走運動した両側の下顎頭二点と，フレ アーアウトしつつある前歯部一点，都合三点で䕱位が保持 できる。しかも，前歯を押し出すことなく前歯部でものを かむことができる，通念からすれば，フレアーアウトしつ つある前歯部でものをかめば，下顎の突き上げがフレアー アウトをさらに促進すると考えられるのに，である．左右 両側の下顎頭を滑走運動させた前方位で顎位を保持するこ とが，前歯列に対しては異常に大きな負荷として作用しな いことが明らかになった．アイヒナーの考え方のように臼 歯部に支持がなくても，また，前歯部をフレアーアウトす るような咬合力であっても，下顎の動かし方，使い方に よっては，臼歯部による支持の助けを借りることなく前歯 部のみによってその咬合力をコントロールできることを示 した．症例 2 然りである．奥がみによって生じる歯列 への害を，前がみによって防ぐのである。下顎頭に異常な
後上方への力が作用しなければ，つまり，下顎の使い方が 片側がみ，奥がみにならなければ，上顎前歯部に過剩な負 荷が加わらないことが明白になった。

機械的，形態的な咬合論から出てくる咬合力を臼歯部の 支持によりコントロールするやり方は，臼歯部の支持を重 視するあまり，また，オクルーザルテーブルに頼ろうとす るあまり，下顎の動かし方が，歯列に害を与える蝶番運動 中心の奥がみになってしまう危険性が高い．奥がみによっ て再構築された臼歯部の支持が，以前と同じような奥がみ により，問題を生じせしめた同じ咬合力によって再度破壊 され，またその咬合力により前歯部がフレアーアウトに陥 るという悪循環に陥ってしまう恐れがある（図 98).

咬合力のコントロールには，さらに左右側の下顎頭の動 きの差によって生じるかみ癖が，必要以上に固定化するこ とによってできる片側がみを防がねばならない，症例 1

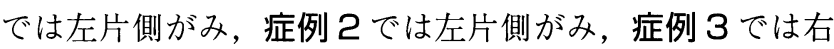
片側がみの悪影響も，奥がみと同様に前歯列に害を与えて いた．かみ癖が固定化して一側の下顎頭の動きが悪化して 片側がみが生じ，さらに反対側の下顎頭の動きが悪化して 奥がみが生じるのであるから，奥がみをコントロールして 前がみにするときには，この左右の片側がみも同時にコン トロールする必要がある。両側の下顎頭の動きを良くし， 意識して，みずからの歯列の中で問題の生じていない部位 を使えるようにすることが咬合力のコントロールの第一歩 である，症例 1 では，37 の尖頭に光重合レジンを築盛し， その部位を認識しやすくし，そこでものをかむのを意識さ せた，症例 2では， 543 スプリントを装着することで 543 部を認識しやすくした。症例 3では，肉や野菜のように 前歯部ではかみにくいものは，歯周の組織がしっかりして いて動摇することのない左側の犬歯部でかむように指導し た。以上のことから，片側がみによる影響を排除した。

\section{5. 臼歯部に支持が存在するのに, 上㖽前歯部がフレアー} アウトすることに対する一考察

症例 3 の右側前歯部における歯槽部の重度な骨吸収に ついて. 形態学的視点からは， 毛歯部の低バイトが理由と して挙げられそうだが，それだけでは図95のような症例 について説明できない，これらの症例は，且歯部に支持が 存在しても，下顎前歯部が上顎前歯部を突き上げる状況に なりうることを示している.

症例 3 をみると, 前方滑走運動時, 上下の右側臼歯部 の間隙が左側より狭くなる。これは，前方運動時に動きの 良い左側の下顎頭だけが前下方へ降りてきて，動きの悪い 右側の下顎頭は元の位置のままであるために起きる現象で 
ある．前歯部を使うとき，両側の下顎頭が前方滑走運動し なければならないのに，左右両側の下顎頭のうち，動きの 良い一方の下顎頭のみが前下方へ動く．動きの悪いもう一 方は，後上方への力によって前下方へ動かそうにも動かせ ない，そのため，下顎頭が後退位付近に残ってしまう状況 になる，前歯部を使うとき，下顎が不十分に側方運動した ような状態になり，曲がったまま蝶番運動せざるを得なく なる. 症例 1，2では左側へ, 症例 3 では右側へ曲がって 蝶番運動せざるを得なくなっていたとみられる。しかも， 本人は側方歯群ではなく前歯部を使掞うと思っているので あるから，始末に悪い。このときには，少なからず下顎は 前方および側方クリステンセン様の動きをしているため, 臼歯部に間隙が生じる.上下前歯部しか接触しないために, もののかみ方によっては症例 1 のように，下顎前歯が上 顎前歯の内側を押すような状況になることもある。そのよ うな状況のときは臼歯部に支持が存在するのに，前歯部が フレアーアウトという状態になる，上顎前歯部に炎症でも 存在すれば，歯周疾患の悪影響も受けて速やかにフレアー アウトの状態が進み，前歯部の竪失という状況になってケ ネディーの $\mathbb{N}$ 級という歯牙欠損状態に結びっく． 臼歯部に 支持が残った状態でも，フレアーアウトする状況となる。

\section{6. 弱いカの累積力に対するコントロール}

咬合力のコントロールその 1 で簡単に記したが，生体に は害にはならない程度の力でも，それが累積すると害にな るということがある．裖創が例としてあげられる，そのよ うな弱い力によって，常に生体は傷つけられていると考え られる。それらが生体に害をもたらさない理由は，生体に は，安静になれば栄養が供給され，少々のダメージについ てはこれを治してしまう治癒回復機能が備わっているから である，裖創の場合を考えれば，いつも同じ側を下にして おけば，同側の押される力により血管が圧迫され，栄養の 供給，老廃物の除去もままならなくなる，栄養の供給が滞 るために微少な傷が治らなくなり，感染でもすれば，その 部位が悪化していわゆる床ずれとなって状態が悪化してい く。このとき，もし適切に反体側を向いて寝るようにすれ ば，下にしておいた結果できた微少な傷は，上側を向くよ うになり，その部位は重みが加わらずに安静な状態が保た れることになり，また，血液の循環もよくなって栄養も十 分に供給され，受けたダメージも大きな傷，すなわち床ず れという状態になることなく回復していく，さまざまな疾 病になったときに体を安静に保つということは, 疾病から 回復するための必須の条件である。もちろん顎口腔系も同 様な状況にあることは言うまでもない.
ただ顎口腔系においては，微少なダメージを及ぼす力が これまでは明白ではなかった。これまで明らかにしてきた ように，顎口腔系にはものをかむという根源的な働きのた めに，常にある種の弱い力が加わり得るような仕組みに なっている．その力は，ものをかむという行為をループ化 するためにかみ癖という形でわれわれの目に触れる。通常 では決して顎口腔系を傷つけるようには働かない力ではあ る。顎口腔系を上手に使えば決して問題が生じることはな い.前がみという状態がそれである。

しかし，かみ癖の固定化により，弱い力ではあっても常 に負荷として一定の部位に加わるようになれば，安静な状 態が得られることがなくなる，小さなダメージを受けた場 合，その状態から回復できなくなる，その部分が感染でも すれば，口腔にはそのような場合，感染を惹起する細菌類 に事欠かないので，あっという間に症例 4 の 7 ように なって歯周の状態が悪化してしまう。症例 2 からは，ポ ケットの形成に対する累積力の影響の大きさが見て取れ る.

歯周疾患の分野では，力というものを後から口腔内に生 じたものと考え，これを探したり，動物実験などにおいて ジグリングフォースなどといって一部の歯に大きな力を加 えたりしてしているが，力は生来存在するのであり，また 累積するものであるという考え方がなかったのである．歯 周疾患の分野でも力をこのように捉えれば，力が歯周疾患 の惹起にこれまで考えられてきた以上に大きな影響を与え ているということが見直されることになるのではなかろう か.

咬合力のコントロールを考える際，200の大きさの力を 100 にすればよいとする考え方がある，が，累積というこ とを考慮すると， 200 の力で 10 経過すると 2,000 である. 100 でも 20 経過すれば 2,000 になってしまうのである。咬 合力を半分にしても，時間の経過により累積した負荷量は 同じになってしまう。従来はこの累積負荷を考慮に入れて はいなかった。ささらに生体には, 安静が得られれば回復す る能力があるということを.

症例 4 を見ると粘膜の圧痕は, 初診時より 8 年後の咬合 カがコントロールされて, 残存歯がすべて M0 になった時 でも深いように見える。つまり，部分床義歯を機能させた まま，重度の歯周疾患に罹患した残存歯の動摇が，M0に 改善された状況において, 負荷は（この場合累積された負 荷が対象となるが）減少してはいないことを示している. 維持歯の具合がよいのであるから，より大きな力を使って かんでいるのであろう．図130のような圧痕を刻む負荷 が加わっているのである。このような状況は，単に200の 
力を 100 にすればすむとする，咬合力のコントロールのや り方からでは説明がつかない.

かみ癖の視点からの解説を以下に述べる．症例 4 の患 者は両側の下顎頭の動きが悪く奥がみとなっており, 中で も右側の下顎頭の動きが悪く右片側がみとなっていた. 右 側の大臼歯部でしかものをかめなくなっていて，かみ癖と なった】にのみ大きな負荷が不断に加わったため, 軽度 の歯周疾患になっても安静な状態を得て回復することがか なわず，重度の歯周疾患に陥ってしまった。このとき咬合 力から生じる負荷がほとんど加わらなかったのが|34 部で ある。そこで，まず，右側の下顎頭の動きをよくして左側 滑走運動を行えるようにし，34部を使えるようにした． かみ癖による負荷を, 歯周の状態の悪化している7功 歯周の状態の良好な 34 部に移した。さらに，前がみをで

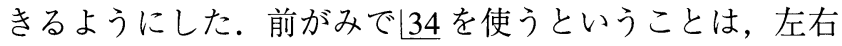
の大臼歯部に理不尽な負荷を加えることを防いで， 717 を 安静な状態に保持することができるようになり，歯周の回 復能力を高めることにつながった。 その結果が，7|の歯周 疾患の良化に結びついたのである。その後は，前がみに よって歯列のどの部位でもまんべんなく使えるようにな り，負荷も一カ所に加わることがなくなった。前記したと おり，顎口腔系も生体の他の部位と同じょうに，多少の傷 が生じたとしても，安静という状態が得られれば，回復す る力が存在するのである。咬合力をコントロールするため には，負荷を一カ所に集めて M3 を作り，負荷の加わらな い残りすべてを M0にするのではなく，負荷を満遍なく分 配してすべてをM1にすることを目指すのである．M3 か らでは，安静にして栄養が供給されたとしても回復はおぼ つかなくなる．M1であれば，安静にすれば栄養の供給が

\section{参考文献}

1）石幡伸雄, 野村義明他：咬合力のコントロール その 1 顎口 腔系にとって危険な力の捉え方. 顎咬合誌，24：109-119, 2004.

2）石幡伸雄，野村義明他：咬合力のコントロール その 2 咬合 力をコントロールするために知っておくべきこと．顎咬合 誌, 24 : 302-315, 2004.

3）石幡伸雄, 野村義明他：咬合力のコントロールその 3 かみ 癖の矯正。顎咬合誌，25：90-104，2005.
十分になされ，簡単にまた M0に戻り得る。顎口腔系は下 顎頭の動きが制限されることなく，それによって生じる負 荷を適切に配分できるように歯列を使えるような状況に なっていれば，咬合力が比較的大きくとも，顎口系は適応 できることを，症例 4 は示した.

\section{おわりに}

咬合力のコントロールについて，これまでは問題を起こ している力を見つけて，その力を除去すればよいとする考 え方であった．が，問題を生じることがないとされる生来 存在するかみ癖による力が, 下顎の運動制限が強まって下 顎の使い方が片側がみ，奥がみとなるために歯列の一部分 に集中することにより，歯列に問題が生じることになる． かみ癖の視点からすれば，咬合力をコントロールするため にはこの力を制御する必要があると考えるのである。下顎 の運動制限を解除するためには，かみ癖の矯正法によって 下顎の使い方を前がみにする．問題の生じている歯列の部 分を外して, 問題の生じていない歯列部分にかみ癖を作る ことによって, 問題の生じている部分を安静に保って回復 を待つようにする，そのような理念に基づいて咬合力をコ ントロールした症例を提示した．今後日常の臨床で，それ までの考え方では認識できない力が作用して，歯列上に問 題が生じているような症例に遭遇した場合には, 以上のよ うな視点から捉え直してアプローチしてみることをお薦め する．かみ癖の視点に興味を抒持ちの方は拙著「顎関節症 はなおせます」(問い合わせ先：材料店，あるいはクイン テッセンス出版 TEL：03-5842-2270）を御高覧いただけ れば幸いである。これまで咬合上の問題で曖昧であった部 分などが明解になること請合いである.

4）宮地建夫：欠損歯列のレベルとリスク．補緅臨床，37： 481-509, 2004.

5）大山喬史, 石井拓男他 : 補綴の症型分類で何が変わるのか. デンタルダイヤモンド，2：148-155，2005.

6）小林之直, 宮田隆他：歯周 - 咬合コンプレックス（POC） に関する考察。顎咬合誌，22：318-323，2002. 